\title{
Nano Carbon-based as Supercapacitor Electrode from Cocoa Skin
}

\author{
Zulkaisi Dwi Pangarso ${ }^{1, *}$, Lina Cahyaningsih ${ }^{2}$, Kahfi Imam Faqih Kurnia ${ }^{3}$, Dyah Purwaningsih ${ }^{4}$ \\ ${ }^{1}$ Physics Education Department; ${ }^{2,3,4}$ Chemistry Department, Faculty of Mathematics and Science, UNY, \\ Jl. Colombo No.1 Yogyakarta 55281, Indonesia. Tel. +62-274-586168. \\ Email*: zdpangarso@gmail.com
}

\begin{abstract}
Most cocoa shells contain carbon which can be used as an electrode. Through nano carbon, cocoa skin has the potential to be an electrode material in supercapacitors. Nano carbon is a form of carbon that has a large surface area and pore volume. Material characteristics through FT-IR test showed that the intensity of wave absorption in the graphite group (C-C) decreased which indicates an increase in carbon. The XRD results show that carbon nano has a peak of purity close to graphite at $2 \theta: 24.75^{\circ}$ on the lattice values (002). So that the nano carbon based supercapacitor electrode has an electrode resistance value of $0.0307 \mathrm{~S} / \mathrm{m}$ with a specific capacitance value of $5.19 \mathrm{~F} / \mathrm{g}$.
\end{abstract}

Keywords: Cocoa skin, nano carbon, supercapacitor

Abbreviations: HEM (High Energy Milling), FT-IR (Fourier Transform Infrared Spectroscopy), XRD (X Ray Diffraction), Brunauer Emmett-Teller (BET), Carbon from pre carbonization (S1), Nano carbon after actvation (S2)

\section{INTRODUCTION}

Nowadays electricity has become a part of human life and also influences technological development. All of these technologies can't be separated from electricity as a source of energy. Electronic devices currently require large electrical power, in other words, they require large energy storage devices as well. Batteries as one of the energy storage devices that are currently mass used, still have some disadvantages, one of which is the small load capacity and the charging rate is still low. So that the use of this technology requires more efficient storage of electrical energy.

Supercapacitors are a form of energy storage that has advantages over conventional capacitors and batteries. The supercapacitors sophistication is shown in its high energy density (103-104 W/kg) (Goubard, 2016), long cycle life stability ( $>100,000$ cycles) (Feroldi, 2016), fast charging time (Hsu, 2014), and safe for the environment (Yin, 2016). Supercapacitors are usually used to manage electric and hybrid vehicle loads, as conventional vehicle starters, telecommunications, electronics that require high power impulses (electrical devices, digital cameras, cellular devices), and electricity storage in solar and wind power plants or as backup power.

On the other hand, Cocoa (Theobroma cacao L.) is one of Indonesia's mainstay commodities, thus placing Indonesia as the third largest cocoa producing country in the world. The total area of cocoa plantations in Indonesia reaches 959,000 ha. Over the past fifteen years, cocoa production increased to 70,919 tons in 2010. If the proportion of waste reaches $75 \%$ of production, then cocoa pods reach 53, 190 tons per year
(Kamelia, 2017). Nowdays the use of cocoa waste is limited to animal feed and fertilizer.

Based on research that has been done (Misran, 2009) that the skin of cocoa contains about $23-54 \%$ cellulose, lignin of $60.67 \%$, holocellulose $36.47 \%$ and hemicellulose $18.90 \%$ (Wijaya, 2014). The content indicates that the skin of cocoa can be processed into charcoal which contains a lot of carbon. Cocoa skin charcoal is produced from the pyrolysis process at a temperature of $350^{\circ} \mathrm{C}$ with a total carbon of 42.5745.53\% (Loppies, 2016).

In some studies, cocoa skin carbon is only used as a waste adsorbent. Though carbon is one of the important components in making electrodes for supercapacitors. Judging from the carbon potential of cocoa skin as the adsorbent, it does not demand the possibility for cocoa skin carbon to be processed into supercapacitor electrodes. Activated carbon has characteristics of a large surface area, by modifying the surface also has an influence on the characteristics of a carbon material, especially as a supercapacitor electrode material. Modification of activated carbon into nano size can increase its performance by increasing surface area so that it can increase ion capture and charge storage.

\section{MATERIALS AND METHODS}

\section{Tools and materials}

The tools that used in this research are furnace, HEM, BET, XRD, FTIR, potentiostat and multimeter. Materials that used in this research are cocoa skin, $\mathrm{KOH}, \mathrm{KCl}$ solution, aquades, PVA, 96\% ethanol, carbon glue and stainless steel. 


\section{Procedures}

\section{Carbonization of cocoa skin}

Dry cocoa skin are inserted into the pyrolysis column for combustion and take place continuously at $350^{\circ} \mathrm{C}$ for $2-3$ hours under little or no oxygen.

\section{Reducing carbon size}

The process of reducing carbon size using the HEM PW 700i Mixer Mill for 60 minutes, so it become nanometersized particles.

\section{Nano carbon activation}

Activation by mixing carbon with $3.5 \mathrm{M} \mathrm{KOH}$ at a ratio of $1: 4$ at $50+1^{\circ} \mathrm{C}$ for 18 hours and then dried using an oven at $120^{\circ} \mathrm{C}$. The carbon which has undergone drying is pyrolysis at $700^{\circ} \mathrm{C}$ for 2 hours before it is cooled using a desiccator. After being cooled then washed using hot water to neutral $\mathrm{pH}$ and $\mathrm{HCl} 0.1 \mathrm{M}$ (Fitrah, 2017).

\section{Hydrogel manufacturing}

Hydrogel production is synthesized by dissolving the PVA polymer into distilled water and $\mathrm{KCl}$ as an electrolyte source.

\section{Supercapacitor manufacturing}

Supercapacitor electrodes are made by mixing nano carbon with conductive carbon glue then weighed in $1: 1$ weight ratio. The results of the mixture are glued to stainless steel measuring $3 \times 5 \mathrm{~cm}$ with a surface area of $1 \times 1 \mathrm{~cm}$. The procedure for making supercapacitors, two activated carbon electrodes are weighed. After weighing each of these electrodes along with a separator in the form of a hydrogel soaked with a $1 \mathrm{M} \mathrm{KCl}$ electrolyte solution, two active carbon electrodes and a $\mathrm{KCl}$ moistened separator are arranged, where the separator is between the two electrodes.

\section{Data analysis}

In this study, data obtained from the results of experiments and were characterized to obtain final conclusions. The form of analysis of the test results are:

1. Analysis of cocoa skin carbon (S1) functional groups and cocoa skin nano carbon (S2) using FT-IR. Furthermore, the transmittance value in the measurement spectra is matched with the data in the reference table from Ochem Online.

2. Testing the volume and distribution of nano carbon pores using V-Sorb 2800TP and calculated using the BET method.

3. Analysis of the structure of $\mathrm{S} 1$ crystals and $\mathrm{S} 2$ perform testing using XRD. The results of the analysis are processed and presented in a specific graphical form.

4. Conductivity analysis of supercapacitor electrodes using LCR meters. Then calculate the conductivity using the following equation:

$$
\begin{gathered}
\text { Conducitivity }=\text { Thick Material/(Material } \\
\text { Area } x \text { Resistance })
\end{gathered}
$$

Supercapacitor electrode capacitance analysis uses the Cyclic Voltametry method to determine the electrode capacitance value. The charge capacitance capability of the electrodes is then calculated using the equation:

$$
\begin{aligned}
& \text { Capacitance }=(I d+I c) /(\text { Scan Rate } \mathrm{x} \\
&\text { Mass })
\end{aligned}
$$

\section{FTIR function group spectrum}

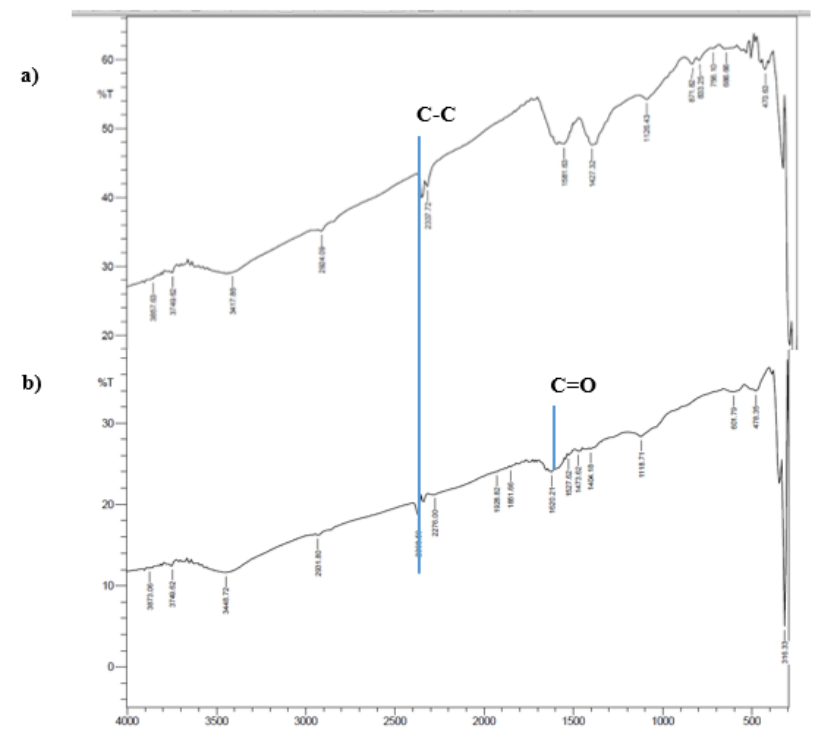

Figure 1. FTIR Spectrum, a) Carbon before activated; b) Nano Carbon after activated and in nanosize

\section{Cristall structure}

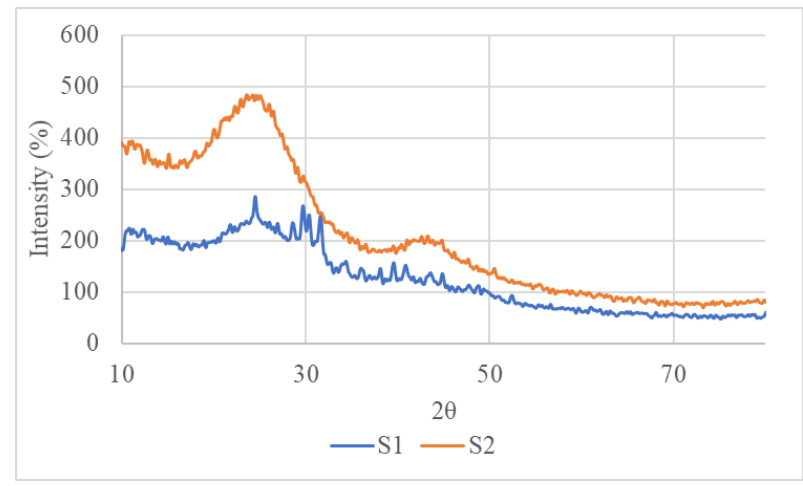

Figure 2. XRD Graph S1 and S2,

\section{Pore volume and distribution (BET)}

Table 1. Porous character of charcoal without activation and nano carbon.

\begin{tabular}{lcc}
\hline $\begin{array}{c}\text { Porous } \\
\text { Character }\end{array}$ & $\begin{array}{c}\text { Charcoal without } \\
\text { activation (Sianipar, 2016) }\end{array}$ & $\begin{array}{c}\text { Nano carbon } \\
\text { (S2) }\end{array}$ \\
\hline $\begin{array}{l}\text { Surface } \\
\text { Area }\end{array}$ & $5,594 \mathrm{~m}^{2} / \mathrm{g}$ & $179.15 \mathrm{~m}^{2} / \mathrm{g}$ \\
$\begin{array}{l}\text { Total pore } \\
\text { volume }\end{array}$ & $0,028 \mathrm{cc} / \mathrm{g}$ & $0.136 \mathrm{cc} / \mathrm{g}$ \\
Pore size & $20,543 \mathrm{~nm}$ & $1.518 \mathrm{~nm}$ \\
\hline
\end{tabular}




\section{Specific capacitance}

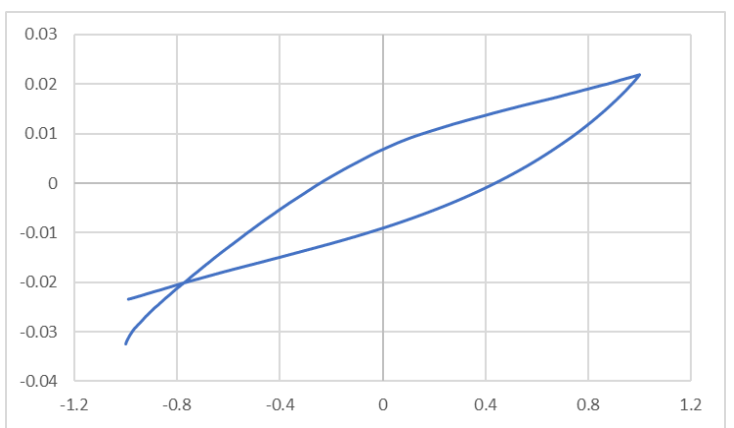

Figure 3. Cyclic Voltametric graph of of cocoa skin supercapacitor electrode.

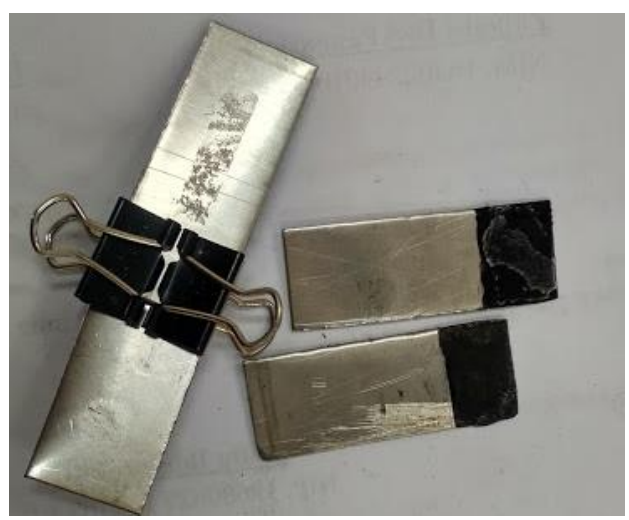

Figure 4. Cocoa skin supercapacitor electrode.

\section{DISCUSSION}

Graphite group (C-C bending) is a constituent of the compound from weathering or combustion of organic compounds with the main constituent elements in the form of carbon (Malarvizhi, 2013) and is present at wavelengths 2450-2300 $\mathrm{cm}^{-1}$ (Aslam, 2011). S1 was formed at $2337.72 \mathrm{~cm}^{-1}$ with transmittance values of $41.56 \%$ and $18.68 \%$ for $\mathrm{S} 2$. The transmittance value of the graphite group (C-C bending) has decreased which indicates the percentage of graphite group presence increases. The formation of graphite groups is due to the high temperature pyrolysis process that has been carried out so that it evaporates almost all organic elements and leaves carbon elements (Oschatz, 2015). The increasing presence of graphite groups shows that the carbon graphite material formed is purer and more conductive to electricity (Konikkara, 2016).

The $\mathrm{C}=\mathrm{O}$ group is a typical group on activated carbon with a peak absorption of numbers $1820-1600 \mathrm{~cm}^{-1}$ (Mentari, 2018). In this case, S2 having a peak of 1620 $\mathrm{cm}^{-1}$ have formed carbon active substances.

As for S1 crystallinity, it has a peak value that is not in accordance with the crystal structure pattern in the JCPDS-ICDD graphite data which is $26.23^{\circ}$. Whereas S2 has a crystal structure pattern which is not much different from JCPDS graphite data. This shows that the process of pyrolysis $\mathrm{S} 1$ to $\mathrm{S} 2$ makes its crystal structure close to pure graphite with S2 crystal size of $9.35 \mathrm{~nm}$.

After reducing the size and activation, the surface area of the S2 increases. The surface area of $\mathrm{S} 2$ is 32 times greater than the cocoa shell charcoal before activation. This happens because in the pyrolysis of high temperature conversion from waste material to carbon material also occurs in the release of volatile components (Abioye, 2015). The increase in surface area is also influenced by the decay of organic components from the carbon matrix which forms a pore resulting from chemical activation using $\mathrm{KOH}$ (Tang, 2015).

S2 pore volume also increased 4 times greater than cocoa shell charcoal. This is caused by the pyrolysis process that forms pore structures at the internal level of molecules and forms carbonic structures in the sample (Channu, 2013). Increased temperature and chemical activation using $\mathrm{KOH}$ will also spur the formation of pore volume in S2 material (Ferrari, 2013; Konikkara, 2016).

The measurement result of S2 electrode resistance is $0.0307 \mathrm{~S} / \mathrm{m}$ with a resistance value of $265 \Omega$. The resistance of the electrode is inversely proportional to its conductivity. High conductivity causes electron transfer to be more effective during the filling / discharging process and causes specific capacitance values to be large

$\mathrm{CV}$ testing was performed using a potentiostat with a scan speed of $10 \mathrm{mV} / \mathrm{s}$ on a $6 \mathrm{M} \mathrm{KCL}$ electrolyte. The $\mathrm{CV}$ test results obtained the specific capacitance value of $\mathrm{S} 2$ of $5.19 \mathrm{~F} / \mathrm{g}$. The specific capacitance value tends to be small because the purity of the crystal S2 is far from graphite. Mismatch of peak crystal purity $(2 \theta)$ due to pyrolysis temperature has not been able to destroy and vaporize components other than the element carbon. Therefore, causing large S2 resistance and the current flowing during CV testing tends to be small so that the specific capacitance value of S2 is small.

\section{CONCLUSIONS}

Material characteristics through FT-IR test showed that the intensity of wave absorption in the graphite group (C-C) decreased which indicates an increase in carbon. The XRD results show that carbon nano has a peak of purity close to graphite at $2 \theta: 24.75^{\circ}$ on the lattice values (002). So that the nano carbon based supercapacitor electrode has an electrode resistance value of $0.0307 \mathrm{~S} / \mathrm{m}$ with a specific capacitance value of $5.19 \mathrm{~F} / \mathrm{g}$.

\section{ACKNOWLEDGEMENTS}

Thank you to KEMRISTEKDIKTI for funding this research through Program Kretivitas Mahasiswa 2019 and all those who helped during the research. 


\section{REFERENCES}

Abioye AM, Nasir F. 2015. Recent Development in the Production of Activated Carbon Electrodes from Agricultural Waste Biomass for Supercapacitors: A Review. Renewable and Sustainable Energy Reviews 52: 1282-1293. DOI: 10.1016/j.rser.2015.07.129.

Aslam Z, et al. 2015. Applied Surface Science Synthesis of Activated Carbon from Oil Fly Ash for Removal of $\mathrm{H}_{2} \mathrm{~S}$ from Gas Stream. 327: 107-115.

Channu VSR, Rambabu B, Holze R. 2013. Colloids and Surfaces a Physicochemical and Engineering Aspects. J Colsurfa 6(8). DOI: 10.1016/j.colsurfa.2013.06.018.

Feroldi D, Carignano M. 2016. Sizing for Fuel Cell/Supercapacitor Hybrid Vehicles based on Stochastic Driving Cycles. Applied Energy 183: 645-658. DOI: 10.1016/j.apenergy.2016.09.008.

Ferrari AC, Basko DM. 2013. Studying the Properties of Graphene. Nature Publishing Group 8(4): 235-246. DOI: 10.1038/nnano.2013.46.

Fitrah ASA. 2017. Limbah Padatan Penyamakan Kulit Ikan sebagai Material Hierarchical Porous Nano carbon untuk Aplikasi Supercapacitor. [Thesis] Institut Pertanian Bogor, Bogor. [Indonesian]

Goubard-bretesché N, et al. 2016. Improving the Volumetric Energy Density of Supercapacitors. Electrochimica Acta. DOI: $10.1016 /$ j.electacta.2016.01.171.

Hsu C, et al. 2014. Electrochimica Acta How the Electrochemical Reversibility of a Battery-type Material Affects the Charge Balance and Performances of Asymmetric Supercapacitors. Electrochimica Acta 146: 759-768. DOI: 10.1016/j.electacta.2014.09.041.

Kamelia M, Fathurohman. 2017. Pemanfaatan Kulit Buah Kakao Fermentasi sebagai Alternatif Bahan Pakan Nabati Serta Pengaruhnya Terhadap Pertumbuhan Ternak Entok (Cairina muschata) 8(1): 66-77.
Konikkara N, Kennedy LJ, Vijaya JJ. 2016. Preparation and Characterization of Hierarchical Porous Carbons Derived from Solid Leather Waste for Supercapacitor Applications. Journal of Hazardous Materials. DOI: 10.1016/j.jhazmat.2016.06.037.

Loppies JE. 2016. The Characteristics of Cocoa Pod Husk Charcoal Produced in Various Pyrolysis Conditions. 105-111.

Malarvizhi TS, Santhi T, Manonmani S. 2013. Acid Treated Lignite Fired Fly Ash for Removal of Zn (II) Ions from Aquous Solution. 4(2): 84-96.

Mentari VA, Handika G, Maulina S. 2018. The Comparison of Funcion Group and Surface Morphology of Activated Carbon from Oil Palm Frond Using Phosporic Acid $\left(\mathrm{H}_{3} \mathrm{PO}_{4}\right)$. Jurnal Teknik Kimia USU 7(1): 16-20.

Misran E. 2009. Pemanfaatan Kulit Coklat dan Kulit Kopi sebagai Adsorben Ion $\mathrm{Pb}$ dalam Larutan. Jurnal Sains dan Teknologi FMIPA Universitas Sanata Dharma Yogyakarta 12(1): 795.

Oschatz M, et al. 2015. Interactions Between Electrolytes and Carbon-Based Materials - NMR Studies on Electrical Double-Layer Capacitors, Lithium-Ion Batteries, and Fuel Cells: 1st ed. Annual Reports on NMR Spectroscopy. DOI: 10.1016/bs.arnmr.2015.08.003.

Tang Y, et al. 2015. A Highly Electronic Conductive Cobalt Nickel Sulphide Dendrite/Quasi-spherical Nanocomposite for a Supercapacitor Electrode with Ultrahigh Areal Specific Capacitance. Journal of Power Sources 295: 314-322. DOI: 10.1016/j.jpowsour.2015.07.035.

Wijaya M. 2014. Pemanfaatan Limbah Kakao sebagai Bahan Baku Produk Pangan. Proceeding in SEMINAR NASIONAL KIMIA DAN PENDIDIKAN KIMIA VI. Program Studi Pendidikan Kimia Jurusan PMIPA FKIP UNS.

Yin J, et al. 2016. Electrochimica Acta from Environmental Pollutant to Activated Carbons for High-Performance Supercapacitors. Electrochimica Acta 201: 96-105. DOI: 10.1016/j.electacta.2016.03.196. 